\title{
What Voters Want from Their Parties: Testing the Promise-keeping Assumption
}

\author{
Dr Annika Werner \\ Centre for Governance and Public Policy, Griffith University \\ Brisbane, Australia
}

Electoral Studies (2019), Volume 57, pp. 186-195

https://doi.org/10.1016/j.electstud.2018.12.006

\begin{abstract}
How should party governments make representative democracy work? Much of the democracy representation literature assumes that voters prefer parties to fulfill the promises of their election campaigns, with higher preference for promise-keeping placed on the party a voter supports. That voters agree with these assumptions, however, remains largely unclear and this is the main hypothesis of this article. Within the context of Australia, this article investigates voter preferences regarding three ideal party representative styles: promise-keeping, focus on public opinion, and seeking the common good. Furthermore, it tests whether voters prefer their party - over other parties - to keep their promises. Based on novel and innovative survey data, this study finds that, generally, voters care least about parties keeping their promises and their preferences are unaffected by their party support. These results, if confirmed in other contexts, not only challenge the primacy of promisekeeping, but also the assumed ubiquitous party effect.
\end{abstract}

Keywords: representation; political parties; attitudes; party support; voters 


\section{INTRODUCTION}

What actions should political parties take after being elected into parliament or government? According to dominant theories of democracy and most prominent models of party government, the parties' main task following an election is keeping promises made before the election and turning their electoral program into public policy (e.g. Naurin 2011; Powell 2000; Pierce 1999; Rose 1969; Thomassen 1991; Thomassen and Schmitt 1997; Thomson et al. 2017). The argument here is that voters give their support to a party on the basis of its election program and expect their selected party to ensure their vote has the intended consequence (Schedler 1998). While a great deal of empirical research has investigated whether parties provide meaningful election programs and whether voters make their electoral decisions on the basis of these programs, there is little research on whether voters share the normative and theoretical assumption that parties should keep their election promises. Thus, this article asks two questions: 1) Do voters value parties keeping promises?

2) Do voters prefer their own party to keep promises more than they prefer other parties to keep their promises?

This study provides answers to these questions by asking survey respondents to judge the desirability of policies with experimentally altered features. The conjoint experimental component of the survey provides the information on whether the party in government, which is randomly assigned, promised the policy or not. Furthermore, it provides information about two alternative bases on which a party could make policy decisions: whether public opinion is in favor or against the policy and whether experts deem the policy in favor of the common good or not. This survey, which also measured respondents' party support alongside a range of controls, was fielded among Australian voters in October 2016. Australia was chosen because of its status as an established Western democracy with a three-year elections cycle and, especially, compulsory voting providing high incentives for voters to engage with 
politics and form preferences towards party behavior. Furthermore, Australian governments are traditionally single-party, meaning that respondents are familiar with a direct attribution of accountability for governmental policies.

The study finds that Australian respondents care considerably less whether a policy fulfills an election promise than whether it falls in line with public opinion or expert advice on what is best for the common good. Furthermore, the analysis shows that respondents' attitudes towards promise-keeping do not change depending on which party is making decisions about the policy. Thus, this paper presents results that, if found to be replicable in other countries, might challenge assumptions of the party representation literature about how voters want party government and representative democracy to function. While this paper focuses on party representation, it also speaks to questions on policymaking as it deals with the way the people want policymakers to behave. However, a more general discussion of policymakers would also include individual MPs, presidents and coalitions as well as the policymaking environment, including advocacy groups. The focus in this article is narrower, as it examines the theories of and expectations towards political parties.

The next section will summarize the argumentation within democracy theory and party government models for the normative importance of parties fulfilling their electoral promises. Furthermore, it will establish two alternative party representative styles that voters may theoretically prefer over promise-keeping. The third section establishes the hypothesis that, according to established theories, voters should place more value on their preferred party than other parties to keep its promises. The fourth section introduces details about the Australian case, and it describes the survey with its conjoint experimental component and a range of control variables. The fifth section first analyses the preferences of voters towards party representative styles, followed by specific preferences regarding their own party. The closing section summarizes and discusses the results. 


\section{PROMISE-KEEPING IN PARTY REPRESENTATION}

Within the theoretical literature on modern representative democracies, one ideal has been established as foundational: through elections, voters and their representatives (usually parties) enter a relationship in which citizens exchange their vote for policy outcomes (Downs 1957; Schedler 1998; Powell 2000; Pierce 1999). Principal to this relationship is that voters will elect the party with the policy program which best aligns with their own policy preferences. To make this relationship meaningful, the theoretical assumption is that voters want the party they vote for to enact the policy program once in power. Thus, parties are understood as transmission belts for the conversion of popular desires into public policy (Converse and Pierce 1986, 499-501, 706). Parties and politicians, in reverse, often claim a mandate to carry out their election platforms (Grossback et al. 2005). At the same time, voters control democratic policymaking through their choices on election day, establishing a clear benchmark against which to judge their representatives during the next election (Royed 1996; Thomson et al. 2017). Consequently, Jane Mansbridge identifies the idea of parties keeping their promises as "one of the central principles of democratic theory" $(2003,515)$ and Andreas Schedler argues that only this promise-keeping ensures that elections have consequences $(1998,194)$. If parties were not striving to keep their electoral promises, if after election day government officials do whatever they want, regardless of any prior campaign commitments, they ridicule the very notion of democracy as well. If electoral results do not produce any policy consequences, elections become mere devices to legitimate arbitrariness and contingency, being mechanisms to replace a random one despotic ruler with another (Schedler 1998, 195).

The same assumption is also part of the Responsible Party Model (RPM), which has been highly influential in party representation research for decades. The RPM also assumes that 
before elections, voters have policy preferences and parties have policy offerings, and during the election, voters choose the best-fitting program to their own interests. Post-election, crucially, elected parties enact their pre-electoral policy proposals or, as Roy Pierce (1999: 9) put it "the elected officials of each party remain united in an effort to enact their issue package into public office." (see also APSA 1950; Thomassen 1991; Thomassen and Schmitt 1997; Powell 2000). On the one hand, this model makes a series of assumptions about voters, especially that they have clear policy preferences and that they are able to choose a party reflecting their preferences. Crucial for the argument here is that RPM suggests that the core responsibility of parties once elected to parliament or government is, again, the program-topolicy linkage (Klingemann et al. 1994; Thomson et al. 2017: 528), meaning to keep their promises by attempting to enact their pre-electoral programs as faithfully as possible.

Given the importance of the promise-keeping ideal in the cited literature, a broad range of empirical research investigates whether and under which circumstances parties behave in line with this assumption. Studies investigate whether parties - both governmental and, when applicable, parties in opposition - implement proposed policies based on the salience of policies in programs and budgets or based on specific pledges. In the salience approach, scholars focus on the relative emphasis that parties place on different policy themes. They examine the congruence between parties' emphasis of policy issues in their programs and subsequent government spending in the policy areas related to these issues. The alternative pledge approach features the specific policy content of parties' electoral programs. Studies using this approach identify pledges in party programs as "commitments [...] to carry out certain policies or achieve certain outcomes" (Budge et al. 1987; Klingeman et al. 1994; Caul and Gray 2002; Thomson et al. 2017). The second step is to evaluate the extent to which these pledges were fulfilled (Artés 2011; Moury 2011; Naurin 2014; Thomson 2011). Both types of studies typically find a high degree of program-to-policy congruence and highlight 
the relevance of this finding for the legitimacy of democracy (see Moury 2011: 35; Moury and Fernandez 2016).

\subsection{Alternatives to promise-keeping}

On the one hand, there is copious theoretical agreement that promise-keeping is central to modern representative democracies, and there is empirical agreement that parties do fulfill their promises. On the other hand, there is very little indication whether voters agree with this normative assumption. Given that democracy rests on the fundamental idea of selfgovernance of the people, their attitudes regarding how democracy should work is essential. Furthermore, recent developments including declining support for democratic actors and institutions as well as increasing support for populism indicate that voters are currently not satisfied with the way democracies work. While the investigation of these phenomena is outside of the scope of this article, it seems reasonable to enquire how voters want representative democracy to work given that their support of the democratic system is central to its success and survival (Easton 1965). Empirical investigation into how well parties perform with regards to one specific representation style (e.g., promise-keeping) is valuable within the frame of democratic theory that focuses on the election-based relationship between voters and elected. At the same time, the mentioned normative assessment of whether democracy works that is based on these studies might be more or less meaningful for voters depending on their attitudes towards the specific representation style. There is some research indicating that voters doubt parties' intention and ability to enact their pre-electoral promises (e.g., Naurin 2011; Thomson 2011), but that does not necessarily mean that voters place the same importance on promise-keeping. If we agree with the quote by Schedler above, the only 
alternative to promise-keeping is arbitrary rule by free agents. In this case, there should be little doubt in the minds of voters about the importance of promise-keeping; however, there are at least two alternative theoretical party representative styles that can make democratic representation work. Thus, the fundamental question here is not whether people want democracy or an alternative form of government but which kind of democracy they want. All three alternatives are based on theories of democracy and representation but on different principles. Thus, this is not a theoretical exercise in determining which democratic theory is 'right' but an empirical enquiry into voters' attitudes towards equally valid alternatives.

The first alternative is based on a democratic model of representation where parties do not focus on representing their voters at the last election, through fulfilling the programs they were elected for, but instead focus on representing their voters at the next election. This 'anticipatory democracy' (Mansbridge 2003, 516-8) is based on the assumptions that parties try to please their future voters for utilitarian reasons. In order to do so, parties deal with a crucial information problem, as they need to predict what are their future voters' preferences (Stimson et al. 1995, 545). Central to solving this problem are public opinion polls and other means to track (and possibly predict) the public mood (Mansbridge 2003, 517; Stimson et al. 1995, 544). This style of representation is also reflected in the model of 'thermostatic representation' (Wlezien 1995; Soroka and Wlezien 2010,2-4), whereby parties adapt their policies until there is no further signal from the public to change it. ${ }^{1}$ Again, the way to gauge the public's need for 'changing the thermostat' is through public opinion. This also speaks to

\footnotetext{
${ }^{1}$ This conceptualisation of the relationship between public opinion and policy is also rooted in, e.g., Easton's analysis of the political system (1965).
} 
the conceptualization of responsiveness, ${ }^{2}$ in which "political parties and leaders [...] sympathetically respond to the short-term demands of voters, public opinion, interest groups, and the media" (Bardi, Bartolini, and Trechsel 2014, 237). The core difference to the promise-keeping ideal is that parties remain consistently updated about which policy decisions are required of them, instead of only at election times.

The second alternative representative style is based on the conception of democracy as leadership selection (e.g., Schumpeter 1942, 269, 285) and representatives as trustees (Pitkin 1967). In the traditional Burkean sense of "trustee," this style rests on individuals (MPs) gaining decision-making capabilities through elections and being tasked to find policy solutions that they agree are best for the nation or, more generally, the common good (Brito Vieira and Runciman 2008; Pitkin 1967). This idea, while distinct, is compatible with the normative demand for representatives to not only focus on the interest of their particular voters, but to find policy solutions that consider the needs of non-voters (e.g. children and future generations, the environment, animals). The original understanding of trustees is not directly applicable to most modern democracies, where representatives are collective actors in the form of parties, thus not being able to form an individualistic belief about the common

\footnotetext{
${ }^{2}$ It is important to note that the literature uses the term responsiveness for multiple concepts. General theorists like Pitkin (1969) and Dahl (1971) refer to responsiveness as the general democratic relationship between voters and their representatives. Both mechanisms that can execute this democratic relationship are also called responsiveness: (a) the responsiveness of parties to their voters at election time (e.g., Powell 2000), and (b) the constant responsiveness of parties to voters' changing preferences (e.g., Bardi, Bartolini, and Trechsel 2014). For clarity, this article only uses "responsiveness" to refer to the more abstract democratic relationship.
} 
good, and who have to make decisions in an increasingly complex globalized world. Thus, one prominent, if not uncontroversial, implementation of this idea is to outsource the decision-preparation to groups of policy experts that are tasked with deliberating and proposing policy that reflects the public interest (Turner 2003; Fischer 2009). To perform this function, these policy experts bring the necessary knowledge from, ideally, all relevant scientific, social, cultural, etc. angles to the table. The deliberation among experts, here, takes the place of the Burkean ideal of deliberation among parliamentarians, who were understood as experts in their own right. It is important to note that this style does not rest on the idea that experts make policy decisions; the democratically legitimized decision is still made by the elected representatives. Instead, experts can integrate the interests of otherwise nonrepresented societal groups and considerations, such as long-term effects on society as a whole, into the decision-making process and arrive at recommendations that benefit the common good (or a close approximation). Thus, instead of following pre-election promises or more fluctuating preferences of the public in opinion polls, democratically legitimized parties pursue the common good by making decisions on the basis of policy experts' advice.

Thus, there are three theoretical representative styles of parties that voters might prefer: (a) fulfilling promises from their electoral program, (b) doing what the public wants, or (c) pursuing the common good with the help of policy experts' advice. Within the theories of democratic representation, none of these three styles is inherently superior to the others: all have their arguments for and against. Much of the empirical literature on democratic representation, and party representation in particular, focuses on the empirical reality of promise-keeping, the degree to which parties confirm to the ideal and which conditions contribute to parties "[doing] the right thing" (Bowler 2016, 10). Therefore, I take the assumption shared among this vast party representation literature and turn it into the following, empirically testable, hypothesis: 
$H_{1}$ : Voters prefer parties to keep their promises over following public opinion or expert advice.

Of course, these are ideal styles, and reality is obviously more complex. One could argue that parties should try to find some 'sweet spot' for any specific policy decision. That these three alternative styles do play a role in political life can be witnessed within public debate, where they often play against one another. With regards to keeping promises, parties have faced the accusation of lying and politicians can suffer vicious attacks if they do not stick to them. Yet, parties that cling to their policy programs have faced criticism of inflexibility and ignoring the public. Parties that want to avoid the accusation of indifference and, instead, listen to the public might be accused of "pandering to opinion polls." Equally, parties that do not listen to what experts say might be charged with pursuing self-interest instead of the best solution for a problem. However, if they do listen, they are considered to be outsourcing decisions to unelected experts instead of doing their work - i.e., sticking to their promises or listening to the public. Further, Spoon and Klüver (2015) have found that parties are more responsive when voters are more polarized on a specific issue. This is but one possible factor influencing which decisions a specific government makes. However, much of the empirical party representation literature, as argued, bases its evaluation of whether parties fulfil their functions and whether representative democracy works on the promise-keeping ideal. Democratic theorists like Schedler (1998), as highlighted above, argue that promise-keeping is central for the basic meaning of democratic elections. Importantly, the purpose of this paper is not to explain real governmental behavior or test all possible preferences voters might have towards party behavior. Instead, building on the different insights in the theoretical literature, this paper investigates the ideal preference of voters. While the literature proposes different options, this article investigates which option(s) voters would choose if they had a direct say. 


\subsection{Voter preferences towards representative styles: Previous evidence}

Just as the public debate is inconsistent, the (relatively recent) literature on voter preferences regarding democratic representation also offers contradictory results. Importantly, most empirical studies analyze voters' preferences for the behavior of individual members of parliament (MPs). ${ }^{3}$ This research found that British voters primarily want their MPs to tow the party line and/or represent their local constituency (Campbell and Lovenduski 2015; Carman 2006). Finnish voters, on the other hand, want MPs to represent the party, the nation, and the local constituency equally (Bengtsson and Wass 2010,63), but, if pressed, sometimes opt for the constituency (Bengtsson and Wass 2011, 154) and sometimes for the nation (Schoultz and Wass 2016, 145). In contrast to both British and Finnish voters, the majority of Spanish voters want MPs to follow their own judgment (Méndez-Lago and Martínez 2002, 74).

More general and comparable to preferences regarding party behavior, Bowler (2016) and Rosset, Giger, and Bernauer (2016) analyze whether European voters prefer that governments should change their policies in response to public opinion or stay true to their promises. They found that two-thirds of the respondents prefer parties to change in line with public opinion while less than one-fifth prefer their governments to stick to promised policies. Echoing the normative preference for promise-keeping consistent with much of the empirical party

\footnotetext{
${ }^{3}$ This discussion is related to but distinct from the literature on voters' preferences for different types of democracies, distinguishing between representative, direct and expert-based or technocratic democracies (e.g., Bengtsson and Christensen 2016; Coffé and Michels 2014). The question of party representation styles is based on the representative democratic system that is established, albeit in varying forms, in all existing democratic regimes.
} 
representation literature discussed above, Bowler interprets governments sticking to their promised policies as "[doing] the right thing” (Bowler 2016, 10). Finally, Werner (2018) shows that voters indeed distinguish between promise-keeping, public opinion and the common good, as well as expecting the latter.

\section{WHICH PARTY? THE ROLE OF PARTY SUPPORT}

Without question, individual voters support certain parties over others, and studies have shown that voters' attitudes toward democracy and its representative components are influenced by whether or not the party a voter supports is in power. Some studies show, for instance, that individuals have higher satisfaction with their democratic system if their party has won the election (Anderson and Tverdova 2003; Clarke et al. 1993; Blais et al. 2017). Supporting the winning party has also been shown to increase trust in various democratic political institutions (Anderson and Tverdova 2003; Wessels 2009). One common explanation for this "winner effect" rests on an instrumental, utilitarian dimension of voters' attitudes towards democracy, meaning that voters connect their party's election victory with hope for policies in their interest (Wessels 2009, 168).

It is plausible that a similar mechanism might influence the type of behavior voters prefer from their parties, and, in particular, whether they want a party to stick to their promises. The spatial theory of voting, for instance, states that voters choose the party that most closely matches their own policy preferences (Downs 1957; Enelow and Hinich 1984). While this theory is contested due to the actual mechanisms of voting (e.g., Iversen 1994), the logic still underpins many models of party representation and, in particular, that of the RPM discussed above. Similarly, voting theories based on group and identity politics (Jennings and Niemi 1981; Iyengar et al. 2012) should lead voters to not only prefer their party to win the election, but then to enact the identity-driven program. Furthermore, research on voters' perception as 
to whether parties do indeed fulfill their promises shows that this perception is partisan (Naurin and Oscarsson 2017; Thomson 2011). Based on each of these theoretical reasonings, the following hypothesis will be tested:

$H_{2}$ : Voters care more about their own party keeping its promises than about other parties keeping their promises.

With regards to voters' attitudes towards post-election decision-making, studies have thus far only been able to test whether supporting the current government has a general effect. Bowler finds that supporting the current government leads to a higher preference for parties keeping their promises instead of following the popular will (Bowler 2016; Bengtsson and Wass 2010, 71). However, these analyses only allow for an indirect inference as to whether voters actually prefer their party to behave one way and other parties a different way. Therefore, the analysis in this study develops a novel survey approach to allow for such inferences as it puts voters into the position of decision makers.

\section{RESEARCH DESIGN: A SURVEY EXPERIMENT AMONG AUSTRALIAN VOTERS}

The empirical part of this study has two necessary components to test the two hypotheses regarding what voters want from parties following elections. First, it must establish voters' preferences towards the three ideal, post-election party behaviors which base policy decisions on parties' electoral promises, public opinion, or the common good as identified by policy experts. Secondly, the empirical analysis needs to test the hypothesis that voters will prefer 
promise-keeping from their party to a larger extend than from other parties. To fulfill these tasks, a purpose-made survey experiment was designed and run among Australian voters. ${ }^{4}$

\subsection{The case: Australia}

Previous research on voters' preferences, especially towards the representative behavior of MPs, focuses mainly on the US or single countries in Western Europe. The current study was conducted in Australia, making it comparable to the earlier cases as Australia is an established democracy with a consolidated party system and over a hundred years of electoral experience. It thus represents a typical case among Western democracies. At the same time, Australia has two specific aspects that make it a particularly interesting case. First, Australia has a very short election cycle of three years and has compulsory voting. This means all citizens with voting rights are forced to engage with electoral and party politics on a very frequent basis. Second, Australia has a stable party system in which one of two parties always forms the government. ${ }^{5}$ Respondents' experience with single-party governments allows them to directly attribute accountability to one specific party without complicating considerations of coalitions and coalition agreements. The two parties in question, which will be used in the experimental setup below, are the Australian Labor Party, on the center-left, and the conservative Coalition. The Coalition is a stable party alliance of the Liberal Party and the

\footnotetext{
${ }^{4}$ Before the experimental component of the survey, all respondents were asked whether they are Australian voters and only positive respondents were able to participate in the survey presented here.

${ }^{5}$ Australia has never experienced a formal coalition at the national level. However, the Labor government of Julia Gillard (2010-2013) was a minority government with the support of the Green Party and independent MPs. This experiment has not—as of yet—been repeated.
} 
National Party of Australia, as well as the Liberal National Party from Queensland and the Country Liberal Party from the Northern Territory. For national elections, the Coalition publishes a common election program, forming one faction within both chambers of the Australian parliament and siting in government or opposition together. The configuration within the Australian states and territories varies slightly as the different parties within the Coalition historically represented different societal groups, with the Liberal Party being more urban based and the National Party and the Country Party being more rural. They are united in their socio-economic and socio-cultural right-of-center positions and are widely perceived as a permanent group. Crucially, the Coalition publishes one national election program, these parties have never formed a government against the other parts of the Coalition and they consistently cooperate at the national level.

\subsection{A conjoint survey experiment}

The experimental setup is a survey with a conjoint design (Hainmueller and Hopkins 2015). This approach confronts respondents with a decision-making situation that consists of contextual information and a limited number of options from which the respondent must choose. The advantage of this approach is that it allows for the combination of a split sample approach with response choices that may vary on multiple dimensions (Vivyan and Wagner 2016,86). Within either the context or the choice, the researcher can control specific aspects to vary between the decision-making situations of different respondents. By investigating the decisions respondents make, their preferences can be directly inferred. While this approach is more challenging to the respondents than a direct question about their preferences, previous research has found that respondents do not discriminate between the importance of different representation styles if asked directly (e.g., Bengtsson and Wass 2010). 
For the survey presented here, respondents were asked to decide whether a hypothetical Australian government should implement a policy. The experiment had multiple steps, which will be laid out in detail below. First, respondents were introduced to the experiment with an introductory statement foreshadowing a hypothetical political situation: "The next few questions are about a hypothetical situation in Australian politics ...." Second, respondents were told whether the Coalition or Labor holds the government in this situation: "Imagine a few years from now, the (Coalition/Labor Party) wins the next federal election and is (returned to government/in government)." This information not only varies the party in government but also makes it clear that all following information and decisions are given in regard to a party in government. The third step introduced the idea that this government needs to make the decision whether to introduce a policy or not. The fourth step then, provided additional information about this policy with regards to whether the government party promised to implement or not implemented the policy, whether the public supports it and whether expert deem it beneficial for the country as a whole. All three principles, thus, have a positive and a negative but no neutral option. This equivalence helps directly testing the relative importance of the three principles against each other. The party promise could be implemented directly. Public opinion is operationalized by referring to polls, because these are the measure of public opinion with which respondents are most likely familiar. The experts' determination of the common good is operationalized by referring to an expert panel and extensive deliberation, indicating that different perspectives and strands of knowledge were included in the discussion and integrated into the solution. While both of these operationalizations are shorthand, they transmit the general idea within the restrictions of a survey experiment. Finally, respondents were asked to judge whether the government should introduce this policy. 
Two of these steps featured two aspects that were experimentally controlled: (1) half the respondents were faced with a Coalition and the other half with a Labor government (step 2 in the setup), and (2) the assignment was randomized via a random generator built into the survey software. The same random generator was used to assign one of eight possible combinations of policy features (step 4 in the survey setup). As shown in Figure 1, each policy situation included three factors that stood for or against a policy: (1) whether the party in government had promised to implement this policy or not implement it, (2) whether the public approved of this policy or was against it, and (3) whether an expert panel deemed the policy beneficial for the general Australian good or not. As each of the three factors had binary outcomes, respondents were faced with one of eight scenarios for their first decision. After making their first decision, respondents were asked the same question for one of the remaining seven scenarios. In line with the controlled usage of the random generator, the eight possible combinations appear equally often in the experimental setup (Table A.1, Appendix).

When respondents were faced with a scenario, they experienced a short temporal delay with no options for activities, increasing the chance that the scenarios were read thoroughly and understood. Respondents were then asked whether they thought that the governing party should implement this policy "definitely," "probably," "probably not," or "definitely not." This answer forms the dependent variable of the following analysis.

Figure 1: An exemplary experimental scenario. 


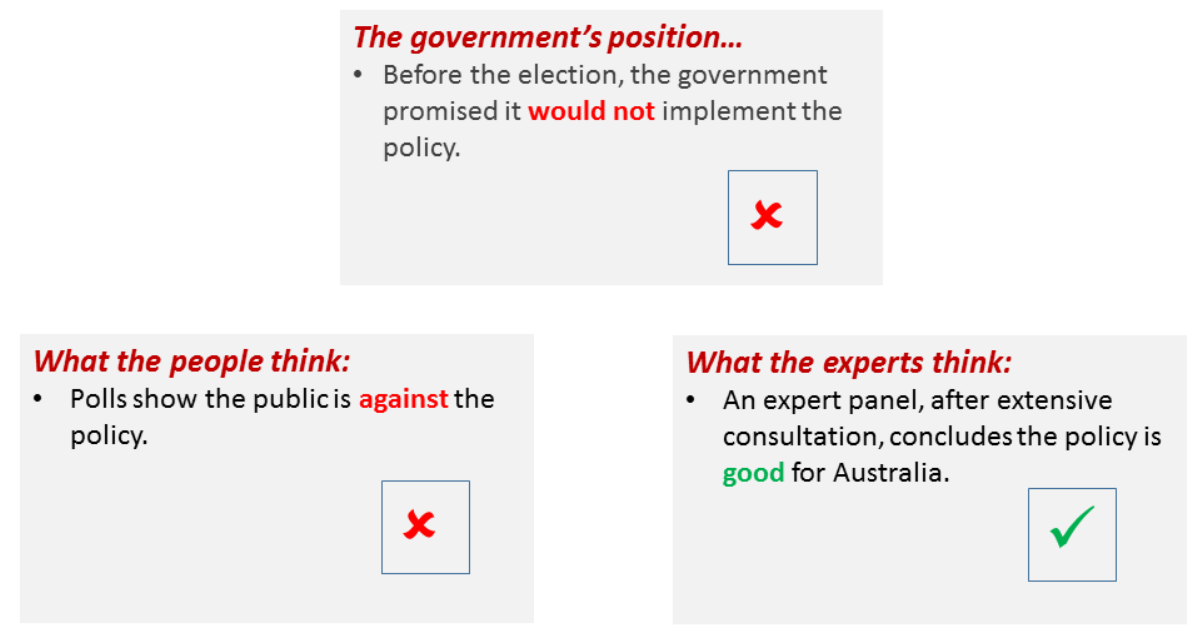

CARD D

To focus the decision on promise-keeping and its alternatives, no further information was given about the policy. Any introduction of policy content - e.g., a specific infrastructure, welfare, or environmental policy - would likely lead to a measurement of policy preferences. Individuals will know their own preferences as well as possibly knowing the position held by the defined governmental party, thus inferring whether they wanted this specific party to fulfill this particular policy promise or not. Similarly, placing the policy into a specific context of time and space could trigger respondents to second-guess whether the policy might have an impact on them personally, and thus alter their decision. Furthermore, there is no information about the salience of the policy, the predictable media reaction, involved individual politicians or other factors that might possibly influence voters' response in a reallife decision. On the one hand, it needs to be acknowledged that real-life political decisionmaking is much more complex than it is possible to reproduce in a survey experiment. Thus, the results here cannot directly be transferred to a specific policy decision in real life. On the other hand, introducing this complexity would drastically decrease the validity of the measure that aims at distinguishing voters' preferences for post-election party behavior on a principal level. 


\subsection{Control variables}

Existing studies of voters' preferences regarding representatives' post-election decisionmaking provide evidence that (a) a variation in preferences should be expected and (b) a number of individual levels are influential. First, an individual's level of interest in politics should influence their preferences for party behavior (Carman 2006; Bengtsson and Wass 2010, 2011; Esaiasson et al. 2016). Individuals with a high level of interest will likely have opinions on policies and prefer them to be heard (Bowler 2016,8), while individuals with little interest in politics might not be bothered with the details of political decision-making, preferring instead that their representatives do what was promised or what experts advise (Bowler 2016, 9). Second, education levels should also influence individuals' preferences, as it influences an individual's understanding of the political process in general (Esaiasson et al. 2016). Higher education gives an individual the cognitive tools to understand the complexity of political decision-making (Carman 2006, 110), thus increasing openness toward expertbased decision-making and weakening preferences regarding promise-keeping. Individuals with low levels of education are likely to be less knowledgeable about the political process and might prefer to have tighter control over their representatives' behavior, opting for decisions based on promises or public opinion.

Finally, a few previous studies have found standard demographic factors to have effects. To enable future theory-building on the basis of an iterative, inductive research process and to avoid omitted variable basis, these are added as further control variables. These factors are (1) age and gender (Bengtsson and Wass 2010, 2011; Esaiasson et al. 2016; Campbell and Lovenduski 2015), (2) respondents' income and work status as controls for their general socio-economic status, (3) rural or urban residence (Carman 2006, 2007; Bengtsson and Wass 2011), and (4) whether respondents have first-hand experience with local party organizations (Werner 2018). 


\section{ANALYSIS: HOW IMPORTANT IS PROMISE-KEEPING?}

The tailor-made survey was fielded online to randomly selected Australian voters aged 18 and above. The survey was run during October 13-18, 2016 by the professional Australian survey company OmniPoll. ${ }^{6}$ OmniPoll owns the contact and demographic information of tens of thousands of Australians that have agreed to participate in surveys. The company contacts potential respondents that are randomly selected within basic demographic strata and provides the weights for gender, educational level, region of residence, and vote intention where the sample does not match the last available census data. The final sample contains 1131 respondents and these post-stratification weights are used. The results reported below are, thus, population estimates. As each respondent evaluated two experimental policy situations, the resulting data set contains 2262 observations, and a survey design approach was applied to the analysis as each respondent's two decisions are connected.

In direct relation to the experimental setup described, the dependent variable for this analysis is the respondents' judgment on whether a policy should be implemented, running from 1 (definitely not) to 4 (definitely yes). The main independent variables are the two sets of experimental factors: (a) the binary outcome for the three representative mechanisms (promise-keeping, public opinion, expert advice), and (b) the decision-making party (Coalition vs. Labor) in combination with the respondent's preferred party. The preferred party was measured through a vote intention question, and it has the Coalition, the Labor Party and the Green Party as possible outcomes. Only respondents that indicated they would vote for one of the Coalition parties (Liberals, Nationals, and Liberal-Nationals), Labor, or

\footnotetext{
${ }^{6}$ This research was funded by the Griffith University New Researcher Grant, grant number 47404.
} 
the Green Party are included in the analysis. There are very few voters for smaller parties, which would lead to highly skewed effects. Non-voters $(\mathrm{N}=113)$, on the other hand, cannot be attributed as either probable Coalition or Labor supporters.

The operationalization of the mainly demographic factors that were influential in previous studies is mostly straightforward (e.g., on gender, age, and respondents' urban or rural residence). Class is measured by respondents' yearly income and work status (Carman 2006), and first-hand experience with parties is identified through a question on whether and how often respondents had participated in local party branch meetings.

The analysis proceeds in two steps. The following section focuses on the effect of the three post-election party behaviors on respondents' judgment while controlling for the party effect. This analysis includes the interaction between all three sets of information, meaning whether or not the party program, public opinion, and experts favor the policy, which is needed to test whether the influence of one principle is dependent on the presence or absence of the other. As the hypothesis sets out a hierarchy of these principles but they are theoretically equal, such an in-depth analysis is necessary to investigate which principle is indeed more important than the others. The second analytical section investigates whether voters regard the role of promise-keeping differently depending on the party in government by focusing on the interaction between the decision-making party and whether or not the party promised the policy. This analysis splits the sample into Coalition and Labor voters to compare their specific preferences towards the promises of Coalition- or Labor-led governments.

\subsection{How important is promise-keeping to Australian voters?}

The first part of this analysis concentrates on how the three post-election party behaviors' effect on how the respondents judged a policy. The following analysis is an ordered logistic 
regression of respondents' judgment, accounting for the survey structure of the data and adding sampling weights (Williams 2016). An ordered logistic regression is preferable to a multinomial logistic regression as the latter does not take the inherently ordered nature of the dependent variable into account. This means that while a multinomial logistic regression tells us the likelihood of falling into one category in comparison to any other, the ordered logistic regression tells us the likelihood of falling into the baseline category versus another category plus all smaller categories. For instance, in the following analysis, where the likelihood for "definitely yes" is the baseline category, the different likelihoods tell us the chance of falling into this category versus "definitely no," versus "definitely or probably no" and versus “definitely or probably no or probably yes." For easier interpretation, the results in Table 1 are reported as odds ratios and predicted probabilities are shown at the level of the four categories, having modeled their ordered nature as described. ${ }^{7}$

Standard ordered logistic regressions work with the proportional odds (or parallel lines) assumption that an increase in an independent variable causes the same change in odds for all judgment categories. Brant's Wald Test shows that this assumption is violated for the variables regarding respondents' age and work status (Brant 1990); age and work status are therefore freed from the assumption, while it is retained for all other variables. Only significant effects $(\mathrm{p}<0.1)$ are displayed for age and work status. ${ }^{8}$

The analysis is run using the gologit 2 command in Stata, which implements ordered logistic regressions. As each respondent was asked to judge two scenarios, which are

\footnotetext{
${ }^{7}$ I do not report the coefficients of ordered logistic regressions as these indicate the effect on the dependent variables in the ordered log-odds scale. This is substantively much harder to interpret.

${ }^{8}$ See Appendix Table A.3 for the full set of results.
} 
therefore connected, this survey design component needs to be incorporated into the model as well. Thus, I use the svy command that allows us to define the survey design and set the primary sampling unit as the respondent. This means that the model accounts for the connection between the two responses by the same respondent.

Table 1: Analysis of the influence of representation mechanisms on judgment

\begin{tabular}{|c|c|c|c|c|c|}
\hline \multirow[b]{2}{*}{ Policy was promise: yes } & \multirow{2}{*}{$\begin{array}{c}\begin{array}{c}\text { Odds } \\
\text { Ratio }\end{array} \\
2.71 \\
\end{array}$} & \multirow{2}{*}{$\begin{array}{l}\begin{array}{l}\text { Std. } \\
\text { Err. }\end{array} \\
\\
\end{array}$} & \multirow{2}{*}{$\begin{array}{l}\mathbf{P}>\mathbf{t} \\
0.00\end{array}$} & \multicolumn{2}{|c|}{$\begin{array}{c}\text { 95\% Conf. } \\
\text { Interval } \\
\end{array}$} \\
\hline & & & & 1.65 & 4.47 \\
\hline Public for policy: yes & 14.23 & 3.25 & 0.00 & 9.09 & 22.28 \\
\hline $\begin{array}{l}\text { Experts for policy: yes } \\
\text { (bases: no) }\end{array}$ & 9.57 & 2.44 & 0.00 & 5.79 & 15.79 \\
\hline Promise*Public & 0.91 & 0.30 & 0.78 & 0.48 & 1.75 \\
\hline Promise*Experts & 1.01 & 0.36 & 0.98 & 0.50 & 2.03 \\
\hline Public*Experts & 0.84 & 0.27 & 0.58 & 0.45 & 1.57 \\
\hline Promise*Public*Experts & 1.29 & 0.61 & 0.59 & 0.51 & 3.25 \\
\hline
\end{tabular}

Vote, base: Coalition

Experiment party: Labor

$\begin{array}{rlllll}\text { Labor } & \mathbf{0 . 6 8} & 0.12 & 0.05 & 0.46 & 1.00 \\ \text { Greens } & \mathbf{0 . 5 4} & 0.13 & 0.01 & 0.34 & 0.86 \\ & 1.00 & 0.20 & 1.00 & 0.67 & 1.50\end{array}$

Vote*Experiment party, base:

Coalition

Labor*Labor

1.83

0.51

0.03

1.05

3.19

Greens*Labor

0.99

0.34

0.97

0.51

1.93

Attendance party meeting, base: never

Education, base: high school

$\begin{array}{rlllll}\text { once } & 1.28 & 0.32 & 0.33 & 0.78 & 2.09 \\ \text { few times } & 1.91 & 0.52 & 0.02 & 1.12 & 3.28 \\ \text { many times } & 1.07 & 0.37 & 0.84 & 0.55 & 2.09\end{array}$

$\begin{array}{rrrrrr}\text { college/apprenticeship } & 1.14 & 0.19 & 0.45 & 0.81 & 1.59 \\ \text { university } & 1.15 & 0.20 & 0.42 & 0.82 & 1.61\end{array}$

Gender: female

$\begin{array}{lllll}1.20 & 0.15 & 0.16 & 0.93 & 1.54\end{array}$

Income, base: $<\$ 50 \mathrm{k}$

\begin{tabular}{rlllll}
$\$ 50 \mathrm{k}-\$ 90 \mathrm{k}$ & 0.95 & 0.16 & 0.78 & 0.68 & 1.33 \\
$\$ 90 \mathrm{k}<$ & 0.88 & 0.16 & 0.47 & 0.61 & 1.26 \\
& 1.02 & 0.14 & 0.88 & 0.78 & 1.33 \\
\hline
\end{tabular}

Age, base: $60+$

$\begin{array}{rlllll}\text { Judgment }>\text { def. not } & & & & & \\ 18-24 & 2.16 & 0.85 & 0.05 & 1.00 & 4.69 \\ 25-34 & 2.14 & 0.71 & 0.02 & 1.11 & 4.10 \\ \text { Judgment }>\text { prob. yes } & & & & & \end{array}$




\begin{tabular}{llllll}
\hline $18-24$ & 0.33 & 0.12 & 0.00 & 0.16 & 0.69 \\
$25-34$ & 0.53 & 0.17 & 0.05 & 0.28 & 1.00 \\
$50-64$ & 0.62 & 0.17 & 0.09 & 0.35 & 1.07
\end{tabular}

Work, base: none

\begin{tabular}{rrrrrrr} 
& \multicolumn{2}{c}{ Judgment $>$ prob. no } & & & & \\
& Full time & 1.42 & 0.29 & 0.09 & 0.95 & 2.12 \\
Constant & & 0.21 & 0.07 & 0.00 & 0.10 & 0.41 \\
\hline
\end{tabular}

$\mathrm{N}=1371$, Population size $=21199, \mathrm{~F}(39,670)=15.72, \mathrm{p}=0.00$

Note: Ordered logistic regression using gologit2 command in Stata; substantial and significant effects in bold; age and work free from parallel lines assumption, only significant results reported. Stata svy command, PSU $=$ respondent.

The results in Table 1 show that all three representative mechanisms positively influence the judgment of the policy, meaning that the odds of a better judgments increase if the party program, public opinion, or experts are positive about the policy. However, the effect of a positive promise is a lot smaller than the effects of the public and expert agreement. Whether a party promised a policy or not matters, but it matters far less than is usually assumed. ${ }^{9}$

Table 1 also shows that the interactions between the three representative mechanisms are not significant overall. Yet, interaction effects are complex and the results in the table can only be interpreted in the event that all main effects take on values of zero, which is meaningful in this case but highly limited. Non-significant interaction can also hide significant effects that are limited to specific levels of the independent variables (Ai and Norton 2013). Therefore, we need to unpack these interaction effects further. To this end, Figure 2 shows the predicted probability of respondents picking one of the four judgment categories in each of the eight possible scenarios.

Each panel in Figure 2 depicts one possible combination of party program, expert advice, and public opinion being for or against the policy. Each bar in the panels shows the probability that a respondent would pick the respective judgment category given the combination of the three sets of information. For instance, if the program, public opinion, and

\footnotetext{
${ }^{9}$ This is confirmed by the model without the interactions, which can be found in Appendix II,
} Table A5. 
experts are all against a policy, a respondent will pick "definitely not" (implement the policy) with a likelihood of .74, "probably not" with a likelihood of .20, "probably yes" with a likelihood of .05 , and "definitely yes" with a likelihood of .01. For each scenario, the likelihood sums up to 1 over the four outcome categories.

Figure 2: Predicted probabilities of four judgment categories, with 95\% CIs.
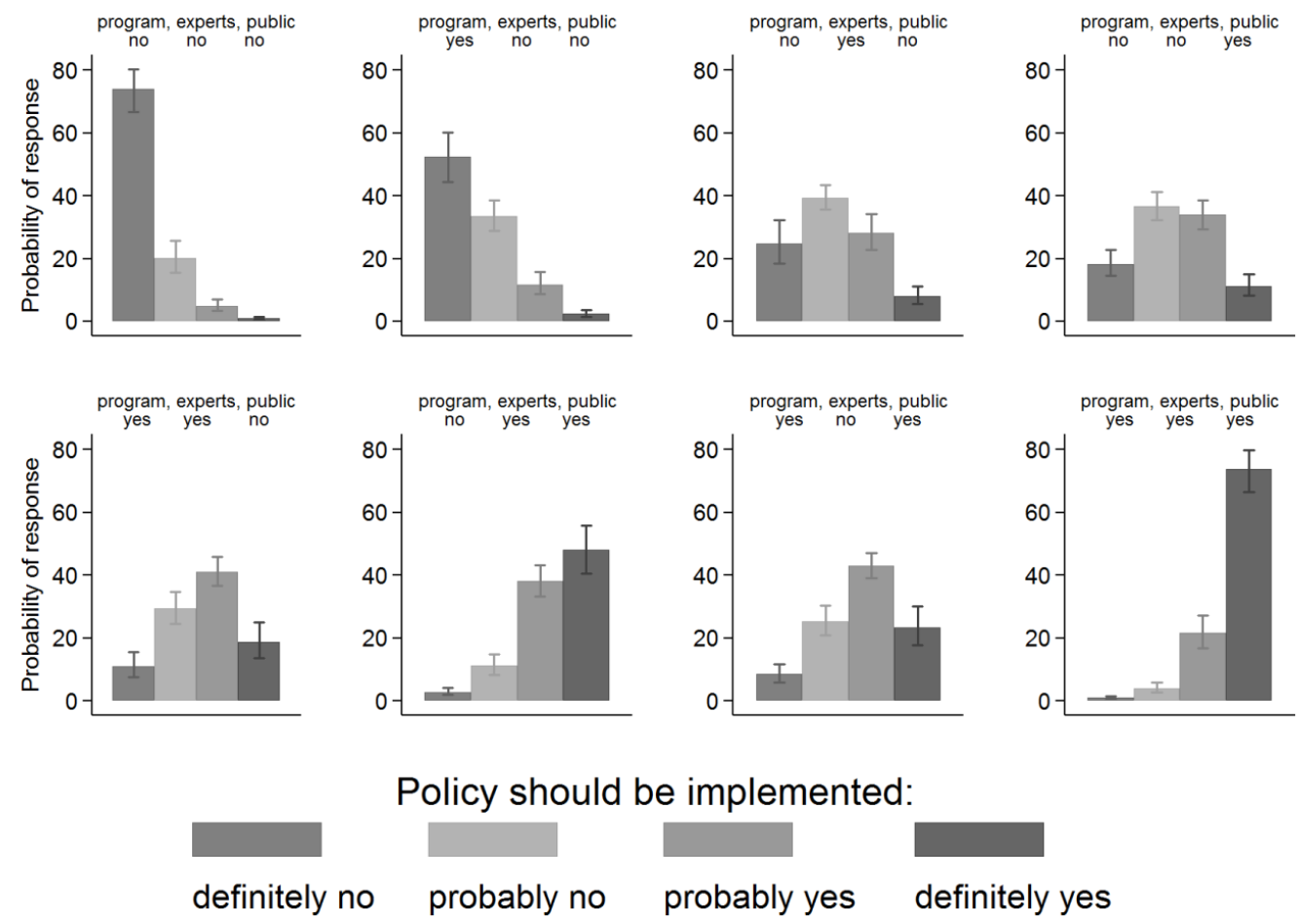

Some of the results are not surprising. If the program, public, and experts are against a policy, the most likely judgment by respondents is to "definitely not" implement the policy. On the other end of the spectrum, a policy endorsed by all three mechanisms has a chance of over .7 to be given a "definitely yes." With regards to the different combinations of positive and negative assessments, the different scenarios do not seem to make much of a difference. In general, the more endorsement a policy gets, the better respondents judge this policy. 
However, there are two scenarios that stand out. First, when a policy was promised by the party program but is opposed by both experts and the public, it has a .5 chance to be outright rejected by the respondents and has the lowest chance of getting a "probably yes" as compared to other policies only endorsed through only one mechanism. This means that being a party program promise alone does not hold much sway when Australian respondents judge a policy. Second, confirming the weak effect of promises again, when a policy is endorsed by experts and the public but is opposed in the party program it still has an approximately .5 chance to be judged as "definitely implement." This scenario is also less likely to be judged with one of the two negative categories than the other scenarios with only two endorsements. Thus, this result indicates that Australian respondents do not prefer parties to keep their promises as much as they prefer them to follow the public and experts. ${ }^{10}$

The second influence under investigation in this analysis is whether the acting party affects this preference. To examine this effect, the model in Table 1 includes the interaction between the party in government, which was set randomly to be one of the major Australian parties (the Coalition or Labor), and the party that the respondent would vote for if there were elections the next weekend. First, Table 1 shows that both Labor and Green voters generally judge policies less favorably than Coalition voters. Second, against theoretical expectation, the party assigned to government does not significantly change the odds of a higher judgment by itself. Third, however, is that one of the interaction terms is significant. Labor voters tend to judge a policy as more favorable if Labor is the governing party. Due to the structure of

\footnotetext{
${ }^{10}$ This result is further confirmed in a robustness check that transforms the dependent variable judgment into a binary 'positive - negative.' Figure B1 in Appendix II shows that, in the cases where two principles are 'yes' and one principle is 'no,' the likelihood for a positive judgment is highest when only the promise was against the policy.
} 
this analysis, it is not possible to draw any detailed conclusions from these results; thus, the next section will investigate this effect further.

\subsection{Do voters adapt their preferences to the party in government?}

To explore the party effect, the second part of this analysis splits the survey population and focuses on Coalition and Labor voters independently. This means that the sample sizes for each of the following analyses is smaller than the complete sample used above and that they are different among each other as there are not the same number of Coalition and Labor voters in the sample. Green voters are excluded here as their sample size is too small for a meaningful interpretation. The split-sample strategy was chosen instead of a three-way interaction as it facilitates interpretation for each voter group by itself. However, given the complexity of the dependent and the three independent variables, this leads to a potential issue with empty cells (see Appendix II, Tables A6-8). Therefore, the analysis was repeated recoding the dependent variable into a binary outcome, and combining the two positive and the two negative judgments, respectively. The results are the same (see Appendix II, Tables A9-10 and Figures B1-2) but hide important details with respect to which categories cause significant results.

The analyses have similar specifications as the one for the whole sample above. The modeling strategy is again an ordered logistic regression, including the survey design specifications. Table 2 shows the model testing for the interaction between promise-keeping and the experimental party for each of the two voter groups. This specific interaction directly tests whether the effect of promise-keeping changes depending on whether a voters' preferred party is in government or whether the other main party is in government. The main independent variables are again binary, and the baseline category is, in all cases, that the respective mechanism rejects the policy. In contrast to the analysis on the whole sample 
above, both experimental factors were freed from the parallel lines assumption. Therefore, Table 2 shows the effects on the likelihood for each judgment category and their respective lower categories in comparison to the baseline category ("definitely yes"). The full results table, including all control variables (age, gender, education, region, income, work status, party meeting attendance), can be found in the Appendix (Table A.4).

With regards to the impact of public opinion and expert advice, Table 2 confirms the results from the first analysis. Both principles affect judgment stronger than party program promises. Whether the party in government has promised a policy or not seems to have the strongest effect on Coalition voters. For Labor voters, this factor only substantially affects the choice between "definitely yes" and any of the lower categories. The interaction between promise-keeping and the governmental party is not significant according to Table 2 . However, these coefficients are constrained to all main effects being zero and further estimates need to be made on the effects. Thus, the following figures show the predicted probabilities for each judgment category dependent on the party that makes the policy decision. In parallel to the models in Table 2, each set of voters is analyzed in turn.

Table 2: Analysis of the party effect on the importance of promise-keeping for Coalition and Labor voters.

\begin{tabular}{|c|c|c|c|c|c|c|}
\hline \multirow[b]{2}{*}{ Judgment } & \multicolumn{3}{|c|}{ Coalition voters } & \multicolumn{3}{|c|}{ Labor voters } \\
\hline & $\begin{array}{l}\text { Definite } \\
\text { ly no }\end{array}$ & $\begin{array}{l}\text { Probably } \\
\text { no }\end{array}$ & Probably yes & $\begin{array}{l}\text { Definitely } \\
\text { no }\end{array}$ & $\begin{array}{l}\text { Probably } \\
\text { no }\end{array}$ & $\begin{array}{l}\text { Probably } \\
\text { yes }\end{array}$ \\
\hline Promise: yes & $\begin{array}{l}3.18^{*} \\
(2.55)\end{array}$ & $\begin{array}{l}3.82 * * * \\
(3.80)\end{array}$ & $\begin{array}{l}2.62 * * \\
(2.85)\end{array}$ & $\begin{array}{l}2.12 * \\
(2.41)\end{array}$ & $\begin{array}{l}1.66 \\
(1.76)\end{array}$ & $\begin{array}{l}3.58 * * * \\
(3.86)\end{array}$ \\
\hline $\begin{array}{l}\text { Experimental } \\
\text { party: Labor }\end{array}$ & $\begin{array}{l}0.77 \\
(-0.62)\end{array}$ & $\begin{array}{l}0.86 \\
(-0.42)\end{array}$ & $\begin{array}{l}0.84 \\
(-0.45)\end{array}$ & $\begin{array}{l}1.51 \\
(1.23)\end{array}$ & $\begin{array}{l}1.47 \\
(1.32)\end{array}$ & $\begin{array}{l}1.90 \\
(1.65)\end{array}$ \\
\hline Promise*Labor & $\begin{array}{l}0.85 \\
(-0.26)\end{array}$ & $\begin{array}{l}0.99 \\
(-0.01)\end{array}$ & $\begin{array}{l}1.62 \\
(0.97)\end{array}$ & $\begin{array}{l}0.96 \\
(-0.08)\end{array}$ & $\begin{array}{l}1.61 \\
(1.12)\end{array}$ & $\begin{array}{l}1.14 \\
(0.27)\end{array}$ \\
\hline Public: yes & $\begin{array}{l}14.61 * * \\
*\end{array}$ & $14.21 * * *$ & $9.38 * * *$ & $17.85 * * *$ & $29.08 * * *$ & $13.47 * * *$ \\
\hline
\end{tabular}




\begin{tabular}{|c|c|c|c|c|c|c|}
\hline & $(7.16)$ & $(10.11)$ & $(7.63)$ & $(9.50)$ & $(13.40)$ & $(9.11)$ \\
\hline Experts: yes & $\begin{array}{l}5.32 * * * \\
(6.04) \\
\end{array}$ & $\begin{array}{l}12.42^{* * * *} \\
(8.60)\end{array}$ & $\begin{array}{l}8.90 * * * \\
(7.06)\end{array}$ & $\begin{array}{l}6.99 * * * \\
(7.73)\end{array}$ & $\begin{array}{l}15.33 * * * \\
(10.05)\end{array}$ & $\begin{array}{l}7.63 * * * \\
(7.22)\end{array}$ \\
\hline Observations & \multicolumn{3}{|c|}{$\begin{array}{c}536 \\
\mathrm{~F}(28,248)=9.43 * * *\end{array}$} & \multicolumn{3}{|c|}{$\begin{array}{c}663 \\
\mathrm{~F}(28,317)=10.79 * * *\end{array}$} \\
\hline
\end{tabular}

Figure 3 shows the predicted probabilities for Coalition voters to answer with any of the four response categories depending on which party is set to be in government and whether it had promised the policy or not. As expected, the likelihood for one of the negative categories is smaller when one of the parties promised the policy in comparison to when it promised not to implement a policy. Furthermore, Coalition voters appear more inclined to judge a policy very negatively when it is introduced by Labor and positively when it is a Coalition policy. However, while Figure 3 shows that there might be some differences, these effects are not significant as most of the confidence intervals overlap. In most scenarios, the probability prediction for one party is squarely within the confidence interval of the other party. This is a strong confirmation of the non-significant result obtained from Table 2.

Figure 3: Predicted probabilities for Coalition voters. 


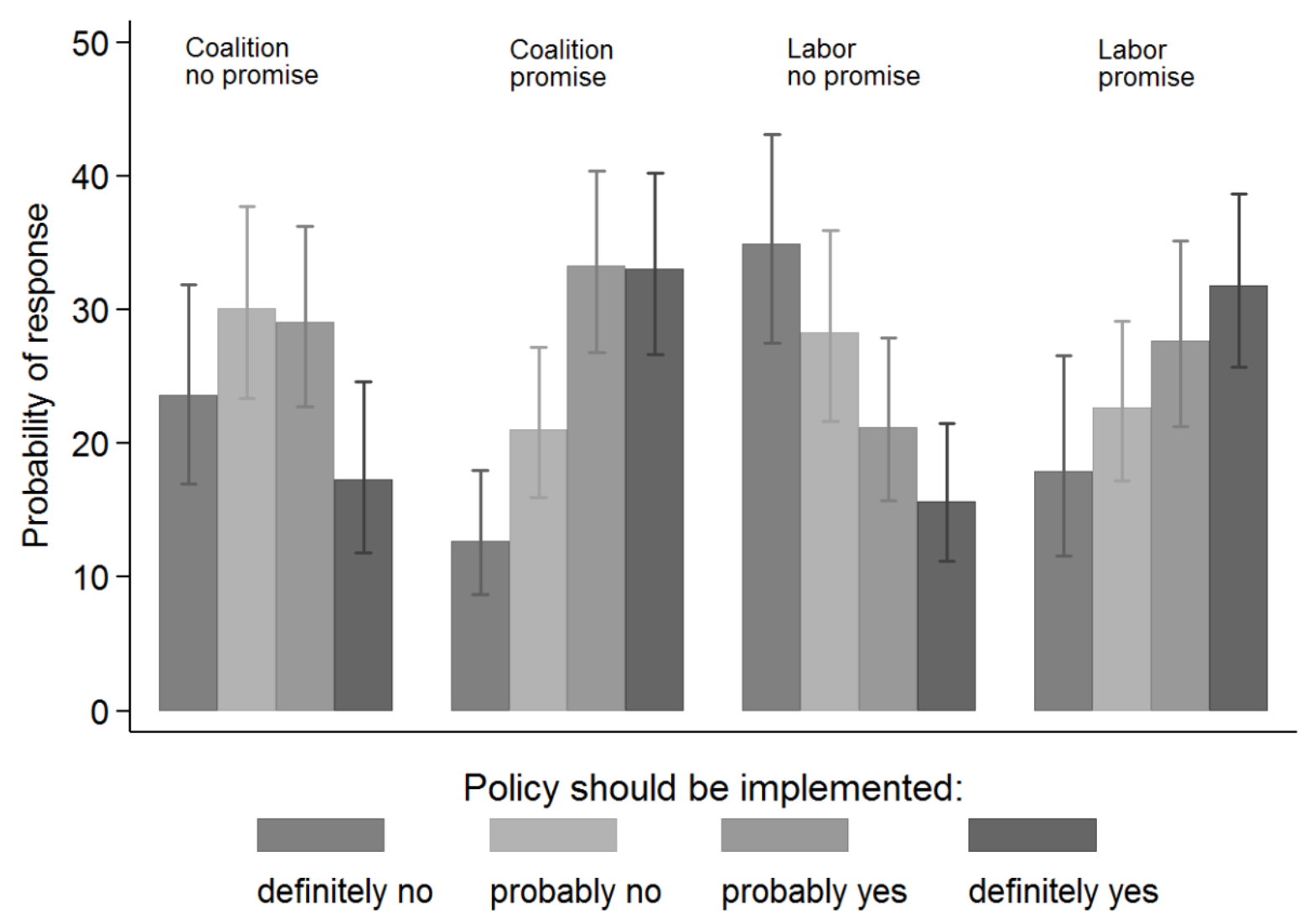

Figure 4: Predicted probabilities for Labor voters. 


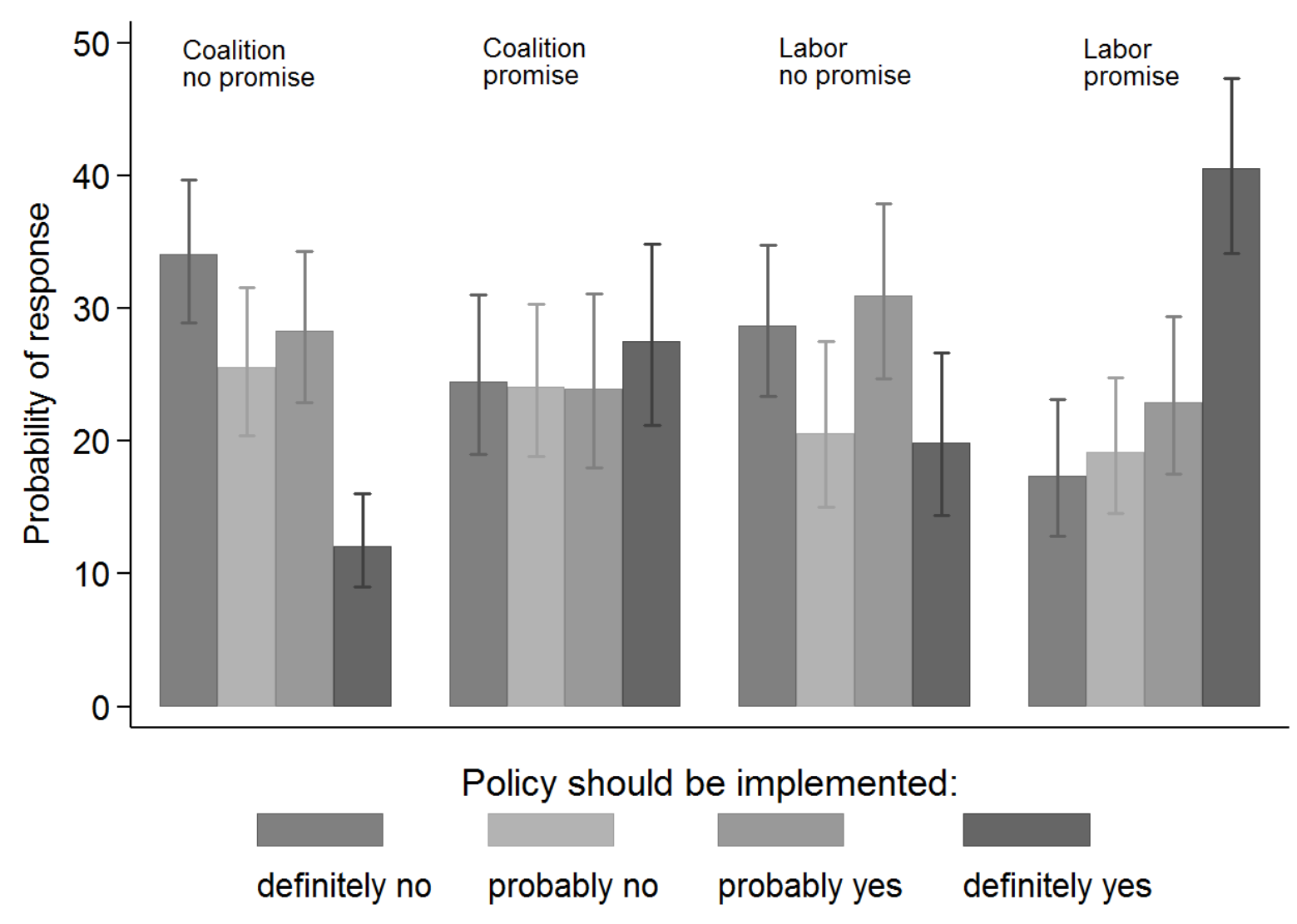

Figure 4 shows a very similar picture for Labor voters. Labor voters seem to tend to attribute one of the negative judgments more readily to policies suggested by a Coalition government than by a Labor government, and they show the reverse tendency when they attribute a very positive judgment. With the exception of the respondents' use of the 'definitely yes' category, Figure 4 shows that there are no significant differences in judgment with regards to the party or whether the policy was promised. The very positive response category, however, shows that Labor voters use this category significantly more for a promised policy by Labor. ${ }^{11}$ However, the other response categories do not show such clear effects.

${ }^{11}$ This effect is confirmed in the robustness check that transforms the judgment category into a 'positive - negative' binary. Figure B2 in Appendix II shows that 'yes' is significantly more 


\section{CONCLUSION}

"[I]n an efficient democratic political system, parties should enact the policies they told the voters they would bring in" (Moury 2011,37). This quote exemplifies the normative and theoretical assumption about what parties should do once elected that underlies a large part of the scholarship on representative democracy and party government. Schedler bluntly states that " $[\mathrm{t}]$ he general norm, which demands that parties honor their campaign promises, is quite uncontroversial" $(1998,191)$. This article asked whether voters share this strong preference towards party behavior and presented the results of a survey among Australian voters. The analysis has shown that Australian respondents consistently rate a policy as more favorable if it is supported by either the public or policy experts, and both of these factors have a strong effect. Whether the policy was promised by a party also has an effect, albeit a much weaker one. Thus, while Australian respondents do not dismiss the importance of promise-keeping, they do not regard it as the singular ideal behavior, as large parts of the democracy and party representation literature assumes. Indeed, the findings suggest that promise-keeping is least important for voters, when compared to the influence of public opinion or expert advice.

Furthermore, this study finds that Australian survey respondents do not appear to adapt their promise-keeping preference based on their support (or lack thereof) for the government party. General systemic evaluations, like satisfaction with democracy, depend on whether a voter's preferred party was successful in the last election (Anderson and Tverdova 2003; Wessels 2009). Usually, when a voter's preferred party won the election, that voter is more satisfied with their democracy and its institutions. With regard to more fundamental principles of party government, however, voters do not seem to make this distinction as they

likely for Labor voters when Labor promises a policy versus when the Coalition promises a policy. All other effects are not significant. 
prefer policies that are based on promises, and it the strength of this preference is not greatly altered depending on whether they generally support the party in government or not. Whether this is due to a strong sense of principle or to a belief that the party in government does not make a difference requires further investigation. Also, the survey experiment presented in this article has its inherent limitations. Party policy making is a complex issue that depends on numerous factors other than which party is in government, including the particular policy, the advocacy environment of the policy, the general media environment etc. It is not possible to test for all of these factors in one experiment. However, this study was able to show that Australian voters have preferences towards party behavior and that they are stable with regards to party support.

To test how far these results travel, further studies could control for, e.g., the influence of the media environment by selecting appropriate cases in a cross-country study. Given the complexity of policies - e.g. whether they have positive or negative, financial or nonfinancial implications for the individual or for specific societal groups - investigating their impact on voters' preferences for party behavior would require either a series of survey experiments that systematically tests for policy characteristics or could be subject of a study based on focus groups. Keeping the limitations of a single survey experiment in a single country in mind, if these results were replicable in other countries, this would mean that whether parties keep the promises made in their election programs might be less relevant to voters than to many, especially, empirical party researchers. If the program-to-policy linkage, which is at the core of party representation models like the RPM, is of little concern to voters, this restricts the functions of these models. This is not to say that this makes these models generally less valuable as they are certainly still helpful in explaining, for instance, party behavior. However, the results of this study call into question whether the dominant model of how parties should make democracy work should indeed be as central and indicate that 
empirical research into how well parties 'do their job' might instead focus on the available democratic alternatives. 


\section{REFERENCES}

Ai, Chunrong, and Edward C. Norton. 2003. Interaction Terms in Logit and Probit Models. Economic Letters 80:123-29.

Anderson Christopher J., and Yuliya V. Tverdova. 2003. Corruption, Political Allegiances, and Attitudes Toward Government in Contemporary Democracies. American Journal of Political Science 47:191-98.

APSA. 1950. Toward a More Responsible Two-Party System: A Report of the Committee on Political Parties. American Political Science Association Vol. 4.

Artés, Joaquin. 2013. Do Spanish politicians keep their promises? Party Politics 19:143-58.

Bardi, Luciano, Stefano Bartolini, and Alexander H. Trechsel. 2014. Responsive and Responsible? The Role of Parties in Twenty-First Century Politics. West European Politics $37: 235-52$.

Bengtsson, Åsa, and Hanna Wass. 2010. Styles of Political Representation: What Do Voters Expect? Journal of Elections, Public Opinion and Parties 20:55-81.

Bengtsson, Åsa, and Hanna Wass. 2011. The Representative Roles of MPs: A Citizen Perspective. Scandinavian Political Studies 34:143-67.

Bengtsson, Åsa, and Henrik Christensen. 2016. Ideals and Actions: Do Citizens' Patterns of Political Participation Correspond to their Conceptions of Democracy? Government and Opposition 51:234-260.

Blais, André, Alexandre Morin-Chassé, and Shane P. Singh. 2016. Election outcomes, legislative representation, and satisfaction with democracy. Party Politics 23:85-95.

Bowler, Shaun. 2016. Trustees, Delegates, and Responsiveness in Comparative Perspective. Comparative Political Studies online first.

Brant, Rollin. 1990. Assessing Proportionality in the Proportional Odds Model for Ordinal Logistic Regression. Biometrics 46:1171-78.

Brito Vieira, Monica, and David Runciman. 2008. Representation. Cambridge, UK, Malden, MA: Polity.

Campbell, Rosie, and Joni Lovenduski. 2015. What Should MPs Do? Public and Parliamentarians' Views Compared. Parliamentary Affairs 68:690-708.

Carman, Christopher. 2006. Public Preferences for Parliamentary Representation in the UK: An Overlooked Link? Political Studies 54:103-22. 
Carman, Christopher. 2007. Assessing Preferences for Political Representation in the US. Journal of Elections, Public Opinion \& Parties 17:1-19.

Caul, Miki, and Mark Gray. 2002. From Platform Declarations to Policy Outcomes. Pp. 204 37 in Parties Without Partisans: Political Change in Advanced Industrial Democracies edited by Russel J. Dalton and Mark P. Wattenberg. Oxford: Oxford University Press.

Clarke, Harold D., Nitish Dutt, and Allan Kornberg. 1993. The Political Economy of Attitudes toward Polity and Society in Western European Democracies. The Journal of Politics 55:998-1021.

Coffé, Hilde, and Ank Michels. 2014. Education and support for representative, direct and stealth democracy. Electoral Studies 35:1-11.

Dahl, Robert A. 1971. Polyarchy: Participation and Opposition. New Haven: Yale University Press.

Downs, Anthony. 1957. An Economic Theory of Political Action in a Democracy. The Journal of Political Economy 65:135-50.

Easton, David. 1965. A framework for political analysis. Englewood Cliffs, NJ: Prentice-Hall Enelow, James, and Melvin J. Hinich. 1981. A New Approach to Voter Uncertainty in the Downsian Spatial Model. American Journal of Political Science 25:483-93.

Esaiasson, Peter, Mikael Gilljam, and Mikael Persson. 2016. Responsiveness Beyond Policy Satisfaction: Does It Matter to Citizens? Comparative Political Studies online first.

Fischer, Frank. 2009. Democracy and Expertise: Reorienting Policy Inquiry: Reorienting Policy Inquiry. Oxford: Oxford University Press.

Grossback, Lawrence J., David A.M. Peterson, and James A. Stimson. 2005. Comparing Competing Theories on the Causes of Mandate Perceptions. American Journal of Political Science 49:406-19.

Hainmueller, Jens, and Daniel J. Hopkins. 2015. The Hidden American Immigration Consensus: A Conjoint Analysis of Attitudes toward Immigrants. American Journal of Political Science 59:529-48.

Iyengar, Shanto, Gaurav Sood, and Yphtach Lelkes. 2012. Affect, Not Ideology: A Social Identity Perspective on Polarization. Public Opinion Quarterly 76:405-31. 
Iversen, Torben. 1994. Political Leadership and Representation in West European Democracies: A Test of Three Models of Voting. American Journal of Political Science $38: 45-74$.

Jennings, Kent, and Richard Niemi. 1981. Generations and Politics: A Panel Study of Young Adults and Their Parents. Princeton: Princeton University Press.

Mansbridge, Jane. 2003. Rethinking Representation. American Political Science Review 97:515-28.

Méndez-Lago, M. and Martínez, A. 2002. Political Representation in Spain: An Empirical Analysis of the Perception of Citizens and MPs. The Journal of Legislative Studies 8:63-90.

Moury, Catherine. 2011. Italian coalitions and electoral promises: assessing the democratic performance of the Prodi I and Berlusconi II governments. Modern Italy 16:35-50.

Moury, Catherine, and Fernandes, Jorge M. 2016. Minority Governments and Pledge Fulfilment: Evidence from Portugal. Government and Opposition, online first.

Naurin, Elin. 2011. Election Promises, Party Behaviour and Voter Perceptions. New York: Palgrave Macmillan.

Naurin, Elin. 2014. Is a Promise a Promise? Election Pledge Fulfilment in Comparative Perspective Using Sweden as an Example. West European Politics 37:1046-64.

Naurin, Elin and Oscarsson, Henrik E. 2017. When and Why Are Voters Correct in Their Evaluations of Specific Government Performance? Political Studies DOI: 0032321716688359 .

Pierce, Rory. 1999. Mass-Elite Issue Linkages and the Responsible Party Model of Representation. Pp. 9-32 in Policy representation in Western Europe edited by Warren E. Miller, Rory Pierce, Jaques Thomassen, Richard Herrera, Soren Holmberg, Peter Esaiasson and Bernhard Wessels. Oxford: Oxford University Press.

Pitkin, Hanna. 1967. The Concept of Representation. Berkeley: University of California Press.

Powell, G. Bingham. 2000. Elections as instruments of democracy: Majoritarian and proportional visions. New Haven, CT: Yale University Press.

Rosset, Jan, Natalie Giger, and Julian Bernauer. 2016. I the People? Self-Interest and Demand for Government Responsiveness. Comparative Political Studies, online first. 
Royed, Terry. 1996. Testing the Mandate Model in Britain and the United States: Evidence from the Reagan and Thatcher Eras. British Journal of Political Science 26:45-80.

Schedler, Andreas. 1998. The normative force of electoral promises. Journal of Theoretical Politics 10:191-214.

Schumpeter, Joseph. 1942. Capitalism, Socialism and Democracy. Harper and Brothers.

Spoon, Jae-Jae, and Heike Klüver. 2015. Voter polarisation and party responsiveness: Why parties emphasise divided issues, but remain silent on unified issues. European Journal of Political Research 54:343-62.

Soroka, Stuart and Wlezien, Christopher. 2010. Degrees of Democracy. Politics, Public Opinion, and Policy. Cambridge: Cambridge University Press.

Stimson, James A., Michael B. MacKuen, and Robert S. Erikson. 1995. Dynamic representation. American Political Science Review 89:543-65.

Thomassen, Jaques. 1991. Empirical Research into Political Representation: A Critical Reappraisal. Pp. 259-274 in Politische Klasse und politische Institutionen: Probleme und Perspektiven der Elitenforschung Dietrich Herzog zum 60. Geburtstag edited by Dieter Herzog, Hans-Dieter Klingemann, Richard Stoess, and Bernhard Wessels. Opladen: Westdeutscher Verlag.

Thomassen, Jaques, and Hermann Schmitt. 1997. Policy representation. European Journal of Political Research 32:165-84.

Thomson, Robert. 2011. Citizens' Evaluations of the Fulfillment of Election Pledges: Evidence from Ireland. Journal of Politics 73:187-201.

Thomson, Robert, Terry Royed, Elin Naurin, Joaquin Artés, Rory Costello, Laurenz EnnserJedenastik, and Katrin Praprotnik. 2017. The Fulfillment of Parties' Election Pledges: A Comparative Study on the Impact of Power Sharing. American Journal of Political Science 61(3): 527-42.

Turner, Stephen. 2003. Liberal Democracy 3.0: Civil Society in an Age of Experts. Sage.

von Schoultz, Åsa, and Hanna Wass. 2016. Beating Issue Agreement: Congruence in the Representational Preferences of Candidates and Voters. Parliamentary Affairs 69:136-58.

Vivyan, Nick, and Markus Wagner. 2016. House or home? Constituent preferences over legislator effort allocation. European Journal of Political Research 55:81-99. 
Werner, Annika. 2018. Voters' preferences for party representation: Promise-keeping, responsiveness to public opinion or enacting the common good. International Political Science Review, DOI: 10.1177/0192512118787430.

Wessels, Bernhard. 2009. Trust in Political Institutions. Pp. 165-183 in The Legitimacy of the European Union After Enlargement edited by Jaques Thomassen. Oxford: Oxford University Press.

Williams, Richard. 2016. Understanding and interpreting generalized ordered logit models. The Journal of Mathematical Sociology 40:7-20.

Wlezien, Christopher. 1995. The public as thermostat: Dynamics of preferences for spending. American Journal of Political Science 39:981-1000. 